\title{
Disentangling the influences of habitat structure and limnological predictors on stream fish communities of a coastal basin, southeastern Brazil
}

\author{
Fabio Cop Ferreira ${ }^{1}$, André Teixeira da Silva ${ }^{2}$, Cristina da Silva Gonçalves ${ }^{3}$ \\ and Miguel Petrere Jr. ${ }^{4}$
}

In stream environments habitat structure and limnological factors interact regulating patterns of energy and material transfer and affecting fish communities. In the coastal basins of Southeastern Brazil, limnological and structural characteristics differ between clear and blackwaters streams. The former have a diversity of substrate types, higher water velocities, and lower water conductivity, while the latter have sandy substrate, tea-colored and acidic waters, and low water velocities. In this study, we verified the relative importance of habitat structure and limnological variables in predicting patterns of variation in stream fish communities. Eight first to third order streams were sampled in the coastal plain of Itanhaém River basin. We captured 34 fish species and verified that community structure was influenced by physical habitat and limnology, being the former more important. A fraction of the variation could not be totally decomposed, and it was assigned to the joint influence of limnology and habitat structure. Some species that were restricted to blackwater streams, may have physiological and behavioral adaptations to deal with the lower $\mathrm{pH}$ levels. When we examined only the clearwater streams, all the explained variation in fish community composition was assigned to structural factors, which express specific preferences for different types of habitats.

Em ambientes de riacho, fatores relacionados à estrutura dos habitats e limnologia interagem regulando os padrões de transferência de energia e matéria, afetando a composição da comunidade de peixes. Em bacias costeiras do sudeste do Brasil as características limnológicas e estrutura dos habitats diferem entre riachos de águas claras e pretas. Os primeiros são compostos por uma variedade de tipos de substrato, possuem velocidades de corrente mais elevadas e baixa condutividade, enquanto os últimos apresentam substrato arenoso, baixas velocidades de corrente e águas escuras e ácidas. Neste trabalho analisamos a importância relativa da estrutura dos habitats e das variáveis limnológicas como preditores dos padrões de composição em comunidades de peixes de riachos. Oito riachos de primeira a terceira ordem foram amostrados na planície costeira da bacia do rio Itanhaém. Capturamos 34 espécies e verificamos que a composição das comunidades foi influenciada por fatores estruturais e limnológicos, sendo os primeiros mais importantes. Uma fração de variação que não pode ser totalmente decomposta, devese à influência conjunta da limnologia e estrutura dos habitats. Algumas das espécies restritas aos riachos de águas pretas provavelmente apresentam adaptações fisiológicas e comportamentais para lidar com os baixos níveis de $\mathrm{pH}$. Quando foram examinados somente os riachos de águas claras, toda a variação explicada na composição da comunidade de peixes foi atribuída aos fatores estruturais, devido a preferências específicas por diferentes características de hábitats.

Key words: Blackwater streams, Clearwater streams, East basin, Restinga forest, Variance partitioning.

\footnotetext{
${ }^{1}$ UNESP, Universidade Estadual Paulista "Júlio de Mesquita Filho", Instituto de Biociências, Departamento de Ecologia. Av. 24-A, 1515, 13506-910 Rio Claro, SP, Brazil. fabiocferreira@gmail.com

${ }^{2}$ UNESP, Universidade Estadual Paulista "Júlio de Mesquita Filho", Instituto de Biociências, Departamento de Zoologia. Av. 24-A, 1515, 13506-910 Rio Claro, SP, Brazil. silva.at@gmail.com

${ }^{3}$ UNESP, Universidade Estadual Paulista “Júlio de Mesquita Filho", Instituto de Biociências, Letras e Exatas, Departamento de Zoologia e Botânica, Laboratório de Ictiologia. Rua Cristóvão Colombo, 2265, Jardim Nazareth, 15054-000 São José do Rio Preto, SP, Brazil. cristina. silva.goncalves@gmail.com

${ }^{4}$ Centro de Ciências e Tecnologias para a Sustentabilidade (CCTS), Programa de Pós-Graduação em Diversidade Biológica e Conservação (PPGDBC), Universidade Federal de São Carlos (UFSCar). Rod. João Leme dos Santos, km 110, 18052-780 Sorocaba, SP, Brazil and UNISANTA, Programa de Pós-Graduação em Sustentabilidade de Ecossistemas Costeiros e Marinhos. Rua Oswaldo Cruz, 277 (Boqueirão), 11045-907, Santos, SP, Brazil. mpetrere@ufscar.br
} 


\section{Introduction}

The importance of limnology and physical habitat as predictors of the structure of fish communities is fully established in the current ecological literature (Schlosser, 1982; Taylor et al., 1993; Jackson et al., 2001; Gerhard et al., 2004; Súarez \& Petrere Jr., 2007). Among habitat predictors we may point out the stability of lateral banks, substrate heterogeneity, presence of wood debris and packs of leaf litter that provide the necessary conditions for fish survivor by offering camouflage against predators, protection from currents, source of food, and substrate for eggs and larval development. In addition, limnological variables including water temperature, $\mathrm{pH}$, dissolved oxygen, turbidity, among others, influence fishes due to their physiological tolerances (Angermeier \& Karr, 1984; Pulsey \& Arthington, 2003; Allan \& Castillo, 2007).

In streams ecosystems, these variables interact through complex pathways regulating energy and material transfer. Due to these interactions, Buisson et al. (2008) argue that identifing isolated responses of each group is a challenge in observational studies. A way to deal with this complexity is to consider a hierarchical view where the variables are linked to each other according to a network of potential causal effects (Pulsey \& Arthington, 2003). For instance, Cruz et al. (2013) considered the riparian zone as the higher level predictor followed by predictors at intermediate levels as bank slope, shade availability, substrate composition, water velocity and water quality. Functional fish composition consisted of the lowest level in this network, which was directly and indirectly affected by the higher hyerarchical levels. The authors concluded that bank slope and substrate composition were the only direct influences and that water limnological traits do not affect the functional fish composition.

Another way to deal with this complexity is to partialling out the variance explained by each set of predictors. Buisson et al. (2008) applyed a partitioning analysis to a large fish data set in French rivers and verified that in 18 out of 28 fish species, the variance assigned the joint influence of thermal regimes and structural factors was higher than the variance assigned independently to each factor. In community ecology, variance partitioning was popularized by Borcard et al. (1992) as a method to extract the spatial and environmental components of community variation. In this context, most applications are motivated to put forward evidences for niche versus neutral theories of metacommunity regulation (Falke \& Fauch, 2010; Landeiro et al., 2012; Siqueira et al., 2012; Grönroos et al., 2013). In addition, few studies have also compared the influence of different sets of environmental predictors related for example to aquatic and riparian habitats, while others had included factors related to predation pressure, resource availability or biotic interactions (Peltonen et al., 2007; Holmes et al., 2011; Siqueira et al., 2012).
In this paper, we studied the stream fish communities of the Itanhaém River basin in SE Brazil. Hydrology and limnology are the main features used to classify the rivers and streams in this region. Mountain streams drain steep areas and have clear waters with high levels of oxygen concentration, whereas some lowland streams draining the Restinga forest have black, poor oxygenated, and acidic waters $(\mathrm{pH}<4)$ (Camargo et al., 1996; Por, 2004). Given these differences, we tried to understand how much of variation in the stream fish communities can be assigned solely to limnological variables ( $\mathrm{pH}$, water temperature, turbidity, and conductivity), or to physical habitat traits (water velocity, substrate composition, stream width, and depth), and how much of the variation due to limnological conditions are also structured by the habitat variables (joint variability).

\section{Material and Methods}

\section{Study area}

The studied streams are located in the coastal plain of the Itanhaém River basin, State of São Paulo SE Brazil. This watershed is the second largest coastal basin of the state with an area of $954 \mathrm{~km}^{2}$ within two metropolitan areas (Baixada Santista and Grande São Paulo). According to Köppen-Geiger classification, the southeastern Brazil has mostly a warm temperate climate (Type - $\mathrm{C}$ with average temperature in the coldest month between 0 and $18^{\circ} \mathrm{C}$ and average temperature in the hottest month above $10^{\circ} \mathrm{C}$ ) (Peel et al., 2007). Nonetheless, in Itanhaém River basin, the climate near the sea coast line is classified as Af (tropical humid and without dry season), while throughout higher elevations in the mountain ranges of Serra do Mar it is classified as Cfa (humid mesothermal without dry season and with hot summers). The rainfall levels are among the highest in the state, and although the rainfall is distributed throughout the year, it peaks between January and March (260 mm/month) with minimum values between June and August (90 mm/month) (São Paulo, 2012).

The soil is covered by the Atlantic rainforest and, while most of the headwaters are located inside preservation areas, the lower portions have a mixture of preserved and degraded areas due to agriculture (banana plantation) and urbanization. The main tributaries of Itanhaém River are Preto, Branco, Mambu, and Aguapeu rivers (Fig. 1). Alike other basins in the region these rivers and streams can be classified as clear or blackwaters due to their limnological and structural characteristics. Clearwater streams have a variety of bottom types from sandy to rocky substrates, highly oxygenated water and a diverse range of mesohabitats such as pools, riffles and runs. Blackwater streams draining the Restinga forest have tea-colored and acidic waters with low oxygen levels, low water velocities and fine-particulate substrate. 


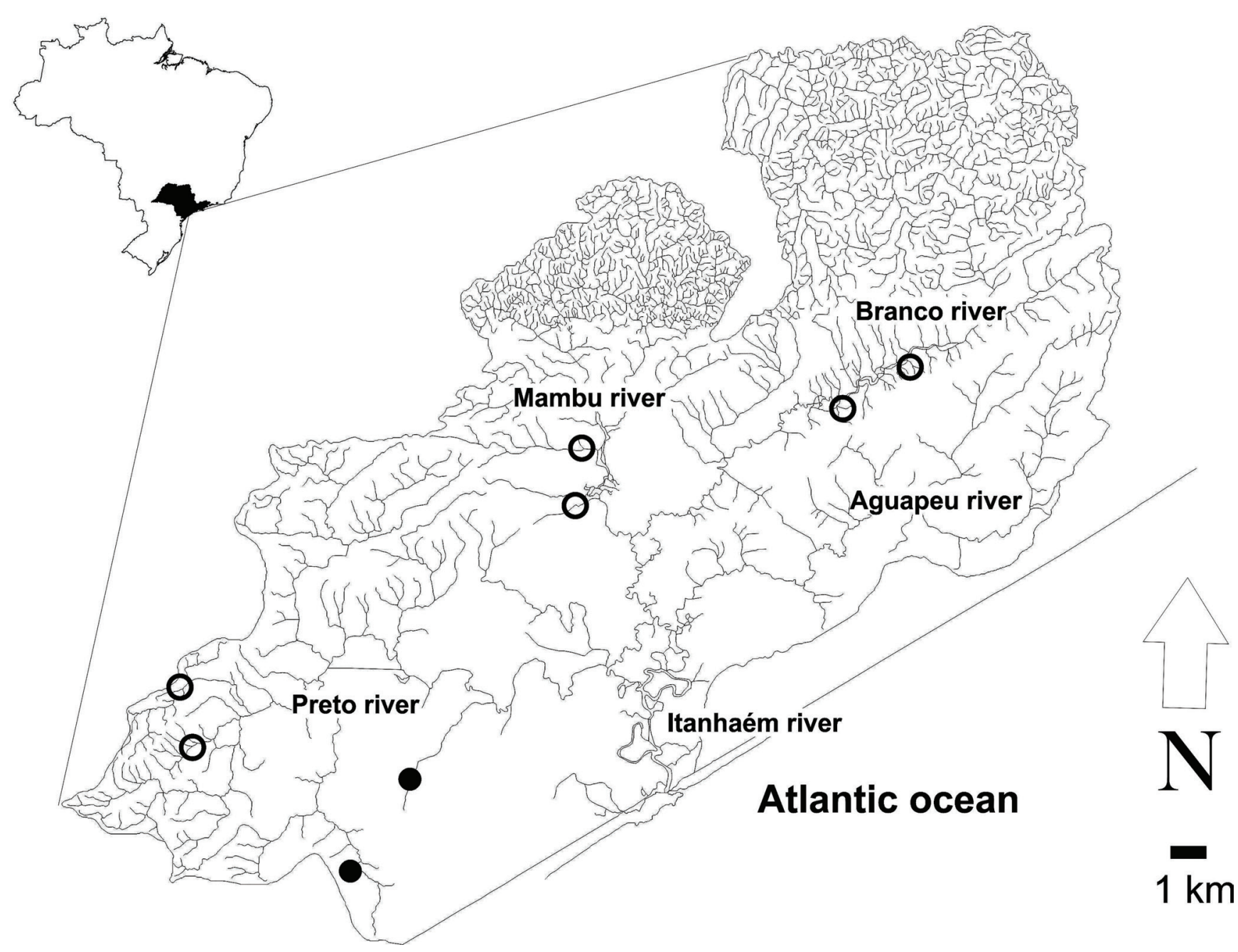

Fig. 1. Hydrography and location of the sampling sites (first to third-order streams) in the coastal plain of Itanhaém River basin, southeastern Brazil. Open circles: clearwater streams. Black circles: blackwater streams.

\section{Fish and habitat sampling}

Fishes were sampled in eight first to third-order streams between 11 and $69 \mathrm{~m}$ above the sea level where the Characidae family is the dominant group (Ferreira \& Petrere Jr., 2009). The clearwater stream sites were near the confluences with the main channels of Branco, Mambu, and Preto rivers (fourth or higher orders) (Fig. 1), while the blackwater streams were inside the Restinga forest. Fishes were caught along 50-m long-stretches (without block nets) by electric fishing gear using a current rectifier (connected to two dip nets) powered by a generator (Yamaha, model EF2600, $2.3 \mathrm{kVA}, 60 \mathrm{~Hz}$, 600 volts, direct current). The samples were carried out by one passage of two people handling the dip nets in the opposite direction to the stream flow. Six clearwater and two blackwater streams were sampled quarterly in 2006 (February to November). However, the blackwater streams could not be sampled in February due to the high water levels, while four clearwater sites were excluded from the analyses in November due to equipment failure measuring the limnological variables.

Fishes were immediately fixed in $10 \%$ formalin, and in the laboratory, the individuals were identified at species level, weighed (g), and preserved in alcohol $70 \%$. Voucher specimens were deposited in the fish collection of the Departamento de Zoologia e Botânica, Universidade Estadual Paulista "Júlio de Mesquita Filho", câmpus de São José do Rio Preto, São Paulo State (DZSJRP) (Table 2). Prior the fish sampling the limnological variables (water temperature, $\mathrm{pH}$, turbidity, and conductivity) were measured in the middle stretch of the sampling sites with an electronic device (Horiba U-10 model). The habitat structure was visually assessed along the 50-m long-stretches. Average channel width was calculated from individual transects taken at each 5 meters. Along these transects and spaced every $1 \mathrm{~m}$, we measured stream depth, water velocity and substrate type. Water velocity was visually classified in 5 categories (V1 - water movement almost imperceptible, practically stagnated; V2 - perceptible movements, but without alterations in the surface; V3 - 
altered surface with small undulations, smaller than $0.5 \mathrm{~cm}$; V4 - surface quite altered, with undulations larger than 0.5 $\mathrm{cm}$; and V5 - turbulent water). The substrate was classified as clay, sandy, gravel, pebble, or boulder. We transformed the qualitative measures of water velocity and substrate in quantitative indexes after Gonçalves \& Braga (2012). The indexes were calculated by the weighed mean according to the formula:

$$
x=\sum\left(f_{i} x_{i}\right) / \sum f_{i}
$$

where $f_{\mathrm{i}}$ is the numerical frequency and $x_{\mathrm{i}}$ is the weight given to substrate (clay $=1$, sand $=2$, gravel $=3$, pebble $=4$, boulder $=5)$, or water-velocity categories $(\mathrm{V} 1=1, \mathrm{~V} 2=2, \mathrm{~V} 3=3$, $\mathrm{V} 4=4, \mathrm{~V} 5=5$ ).

\section{Data analyses}

In order to provide an initial description of how the clear and blackwater streams differ in habitat structure and limnology, a Principal Component Analysis (PCA) was used to ordinate the sampling sites and to describe the pattern of correlation among environmental variables. Turbidity and conductivity were log-transformed to remove the influence of extreme values (Legendre \& Legendre, 2012). Prior to PCA, the variables were centered to zero mean and standardized to unit variance. The mean values for each environmental variable were then compared between clear and blackwater streams by individual $t$ tests.

Partial Redundancy Analysis (pRDA) was used to quantify the isolated effects of each set of predictors (limnological or structural) on community composition. The Hellinger transformation (

$$
\sqrt{n_{i j} / \sum_{j=1}^{S} n_{i j}}
$$

where $n_{\mathrm{ij}}$ is the abundance of the species $i$ in the site $j$ and $S$ the species richness) was applied to the matrix of species abundance, which is indicated to make the matrices of community composition suitable for applying linear methods such as pRDA (Peres-Neto et al., 2006; Legendre, 2008). The data structure used in $\mathrm{pRDA}$ was $\mathrm{Y} \sim \mathrm{X} \mid \mathrm{W}$, were $\mathrm{Y}$ is the response variable (community composition), $\mathrm{X}$ the predictor matrix and $\mathrm{W}$ the conditioning matrix. The objective of the pRDA is measure the influence of $\mathrm{X}$ on $\mathrm{Y}$ after remove the effect of W. Thus, to measure the influence of pure limnological variables we used $\mathrm{pH}$, water temperature, conductivity and turbidity as the predictor group, and the habitat variables as the conditioning matrix. Conversely, to measure the influence of pure structural variables we used the water velocity, substrate, depth, and width as the predictor group and the limnological factors as the conditioning variables. By using pRDA we partitioned the community's total variation in the following fractions: pure limnological variation [a], shared variation (limnological and structural factors) [b], pure structural variation $[\mathrm{c}]$, and unexplained variation $[\mathrm{d}]$. The results, presented as proportions of total variance $[\mathrm{a}+\mathrm{b}+\mathrm{c}+\mathrm{d}]$, were based on adjusted coefficients of determination $\left(\mathrm{R}_{\text {adj }}^{2}\right)$. A randomization procedure (10.000 permutations) was used to test the hypothesis of statistical significance of fractions [a] and [c], and to measure the statistical significance of each environmental variable on pRDA (Peres-Neto et al., 2006).

Variance partitioning was firstly proposed in the context of community ecology to partialling out the spatial from the environmental component of community variation (Borcard et al., 1992). Thus, to decide whether space should be included in pRDA, we run a Mantel test (10.000 permutations) to compare the dissimilarity in species composition (using the Bray-Curtis index) with the watercourse distance (in kilometers) among streams.

As some sites were sampled repeatedly throughout 2005, the observations at the same site but in different months were not completely independent, and ignoring this temporal data structure in the statistical tests would increase the type I error rates. To deal with this in the Mantel test, we did not include the pairwise distances between the same sites sampled at different months. As previously verified, these pairwise comparisons had major influences on the final results as the spatial distances between these samples were actually zero. For the other statistical analysis (t tests and pRDA) the $\mathrm{p}$-values were calculated under restricted randomization (Manly, 2007). Restricted randomization is often applied when simply shuffling the data at random is inappropriate, as when there is some temporal structure, or in block designs (Simpson, 2012). Under this scheme, permutation of the sampling units is restricted by some factor, in our case, the month at which each sample was obtained. Thus, when generating the null distributions, we did not allow for an observation to be shuffled among different months, but only among different sites within months. Considering our sampling design, this procedure provide us with a better control over the type I error rates for testing the spatial effect (i.e., clear versus blackwater sites).

All analyses were performed with $\mathrm{R}$ software ( $\mathrm{R}$ Development Core Team, 2012). Variance partitioning and pRDA was carried out using functions varpart and rda available in vegan package version 2.0-4 (Oksanen et al., 2012). Restricted randomization were done using the options available in permute package, version 0.7-0 (Simpson, 2012).

\section{Results}

The first axis of the PCA isolated black from clearwater streams, accounting for $46.1 \%$ of the variation in the patterns of correlation among environmental variables. Blackwater streams were characterized by fine-particulate substrate, lower velocities, and were deeper and narrower than the clearwaters. 
Table 1. Mean and standard deviation (in parenthesis) for limnological and structural variables in clear $(\mathrm{n}=21)$ and blackwater $(n=6)$ streams, including the results of the t tests.

\begin{tabular}{|c|c|c|c|c|c|}
\hline & & Clearwaters & Blackwaters & $\mathrm{t}$ & $\mathrm{p}$ \\
\hline \multirow{4}{*}{ 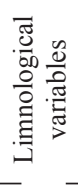 } & Temperature $\left({ }^{\circ} \mathrm{C}\right)$ & $20.82(1.90)$ & $20.19(1.58)$ & 0.74 & 0.503 \\
\hline & $\mathrm{pH}$ & $6.91(0.67)$ & $4.56(0.45)$ & 7.92 & 0.001 \\
\hline & Turbidity (NTU) & $14.49(12.06)$ & $10.33(3.07)$ & 0.07 & 0.939 \\
\hline & Conductivity $\left(\mathrm{mScm}^{-1}\right)$ & $0.031(0.027)$ & $0.075(0.015)$ & 5.16 & 0.001 \\
\hline \multirow{4}{*}{ 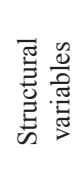 } & Width (cm) & $598.01(268.18)$ & $287.23(188.19)$ & 2.64 & 0.015 \\
\hline & Depth (cm) & $13.33(3.12)$ & $20.91(2.83)$ & 5.02 & 0.001 \\
\hline & Substrate & $3.94(0.44)$ & $2.10(0.21)$ & 9.67 & 0.001 \\
\hline & Water velocity & $2.85(0.27)$ & $1.67(0.68)$ & 6.57 & 0.001 \\
\hline
\end{tabular}

They also had higher conductivity and lower $\mathrm{pH}$ levels. The second axis accounted for $16.2 \%$ of variation, describing the gradients of temperature and turbidity, but did not distinguished black from clearwater streams (Fig. 2, Table 1).

We caught 34 fish species, 29 in clearwater and 19 in blackwater streams, with 14 common species. The four most abundant species were Mimagoniates lateralis, Deuterodon iguape, Characidium sp., and Kronichthys heylandi, being the last three exclusively from or predominantly captured in clearwaters. On the blackwater streams $M$. lateralis, Scleromystax macropterus, Pseudotothyris obtusa, Hyphessobrycon reticulatus, and Acentronichthys leptos were the most abundant. The first three were exclusively captured in blackwater streams, while $H$. reticulatus and $A$. leptos had occasional occurrence in clearwaters (Table 2).

With all sites included, the environmental predictors accounted for $46.2 \%$ of total variation in community composition due to the influence of $\mathrm{pH}$, width, depth and substrate. Pure structural predictors explained $19.3 \%$ of total variation $(\mathrm{p}=0.024)$ while pure limnological factors accounted for a small but statistically significant fraction of $3.1 \%(\mathrm{p}<0.001)$. The highest explained fraction $(23.8 \%)$ was assigned to the shared variation. Removing the blackwater streams, pure structural factors were the unique influence on community composition, accounting for $34.7 \%(\mathrm{p}<0.001)$ of the explained variation, while pure limnological and shared fractions had small and negative values $(-0.05,-0.004)$ (Table $3)$. The watercourse distances among sites were not correlated with community dissimilarity (Mantel test: $r=0.01, p=0.426$ ).

Considering the influence of pure limnological predictors with all sites included (Fig. 3a), pH was significantly correlated to community composition ( $p=0.0473$ ), while temperature $(p=0.154)$, turbidity $(p=0.158)$, and conductivity $(\mathrm{p}=0.113)$ was not. Lower values of $\mathrm{pH}$ were correlated with the abundance of $M$. lateralis, $S$. macropterus, H. reticulatus, A. leptos, P. obtusa, and Characidium sp. while higher values were correlated with the abundance of Phalloceros cf. reisi, Rineloricaria kronei, Awaous tajasica, Hollandichthys multifasciatus, and Bryconamericus microcephalus.
Concerning the effects of pure structural predictors (Fig. $3 b)$, community composition was significantly correlated with width $(\mathrm{p}<0.001)$, depth $(\mathrm{p}<0.001)$ and substrate $(\mathrm{p}=0.006)$, but not with water velocity $(\mathrm{p}=0.109)$. The abundance of the catfishes $K$. heylandi and Rhamdioglanis transfasciatus were correlated with shallow streams, D. iguape with coarser substrate, Characidium sp. and M. microlepis with wider streams, and H. multifasciatus and Phalloceros cf. reisi with narrow channels and fine-particulate substrate.

\section{Discussion}

We verified that environmental conditions in clear and blackwater streams differ in several aspects. The blackwater streams were on average deeper, narrower, predominantly sandy with lower water velocities. They also had higher water conductivities and lower $\mathrm{pH}$ levels. These results evidenced that part of the variation in limnology is structured

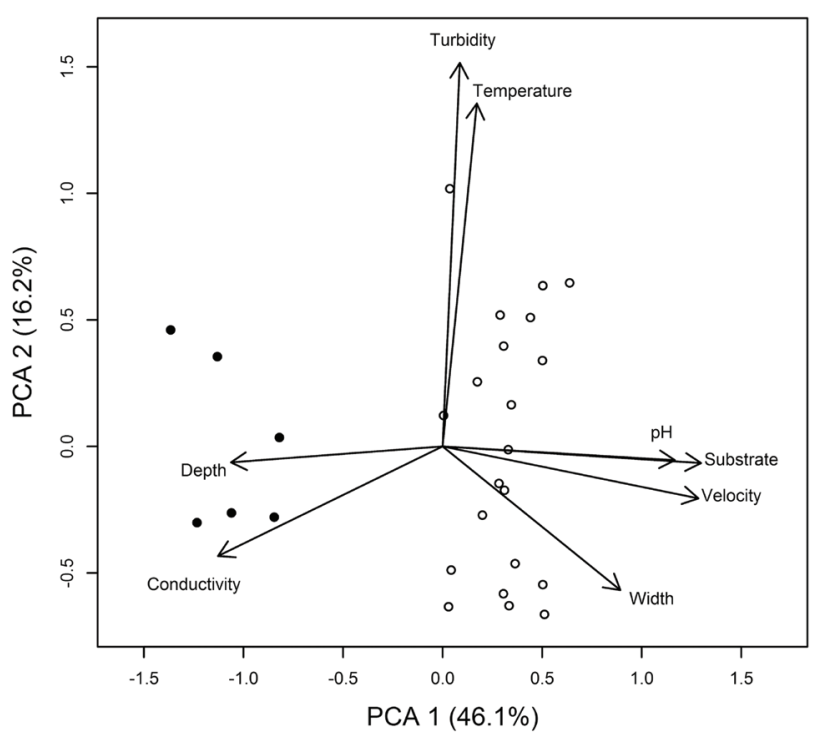

Fig. 2. Results of the Principal Component Analysis (PCA) showing the clearwater (open circles) and blackwater (black circles) sites. 
Table 2. Species abundances in clear and blackwater streams of Itanhaém River basin.

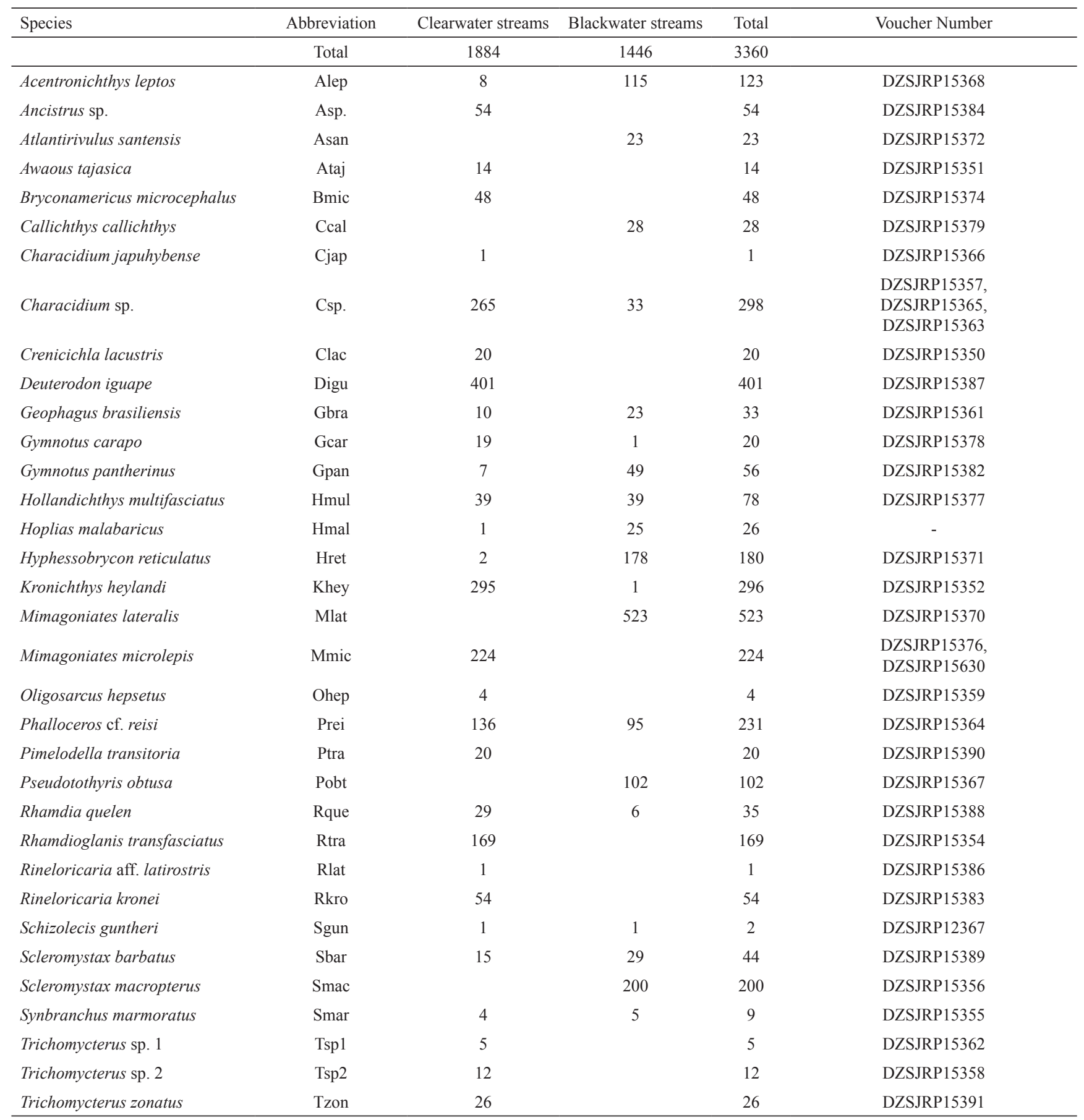

by the physical habitat conditions (Menezes et al., 2007; Gonçalves \& Braga, 2012), pointing out a hierarchical pattern of dependence among abiotic features, where higher levels variables related to habitat structure (riparian cover, shade availability, channel morphometry, substrate and water velocity) influence lower levels variables related to water quality and fish community (Cruz et al., 2013; Pulsey \& Arthington, 2003; Dias et al., 2010). In the Restinga forest for example, where declivity is lower, the streams have low water velocities and depositional characteristics, promoting the accumulation and decomposition of humic substances that causes the acid blackwaters (average $\mathrm{pH}=4.56$ ) (Janzen, 1974). In addition, the proximity with the sea results in higher levels of water conductivity (Por, 2004). Clearwater streams otherwise drain the moutain ranges of Serra do Mar, coming from higher declivities with water velocities, so high that fine-particulate material does not accumulate as in the blackwater streams. 
Table 3. Results of pRDA and variance partitioning for all sites and excluding blackwater streams. Negative fractions were not shown.

\begin{tabular}{|c|c|c|c|c|c|c|c|}
\hline & $\mathrm{p}$-value [a] & $\mathrm{p}$-value $[\mathrm{c}]$ & $\begin{array}{l}\text { Significant variables on } \\
\text { pRDA }\end{array}$ & Limnological [a] & Shared [b] & Structural $[\mathrm{c}]$ & Residual \\
\hline All sites & 0.024 & $<0.001$ & $\begin{array}{l}\mathrm{pH} \text {, width, } \\
\text { depth, substrate }\end{array}$ & 0.031 & 0.238 & 0.193 & 0.538 \\
\hline $\begin{array}{l}\text { Excluding the } \\
\text { blackwater sites }\end{array}$ & & $<0.001$ & $\begin{array}{l}\text { width, depth, } \\
\text { substrate }\end{array}$ & & & 0.347 & 0.707 \\
\hline
\end{tabular}

Given these differences and the relationship between structural and limnological factors, it is expected a complex interaction between fishes and environment, with a high proportion of variation in community composition (23.8\%) assigned to the joint effects of limnology and habitat structure. After removing the blackwater streams from the analyses, it became evident that they were the main source of this joint variability. Considering the isolated effects, a much higher variation was due to structural predictors $(19.3 \%, \mathrm{p}<$ 0.001 ), influenced by depth, width and substrate, stressing the importance of structural complexities to the maintenance of stream fish diversity (Casatti et al., 2009; Dias et al., 2010; Cruz et al., 2013).

Although limnological variables were relatively unimportant in comparison to the structural factors, our results suggest that lower levels of $\mathrm{pH}$ may restrict the distribution of some abundant species (e.g., D. iguape and R. transfasciatus), and favor the occurrence of others (e.g., M. lateralis, $S$. macropterus, $H$. reticulatus, A. leptos, and P. obtusa). It is known that artificial acidification has depletory effects on fishes and aquatic invertebrates (Allan \& Castillo, 2007) because several species are incapable to regulate internal $\mathrm{pH}$, which in turn affects oxygen assimilation (Matthews, 1998), reproduction, and calcium and sodium regulation (Fromm, 1980; Freda \& Dunson, 1984; Hargeby \& Petersen Jr., 1988). Conversely, in natural acidic streams fish richness can be high (Henderson \& Walker, 1986; Otto, 2006) because some species are adapted to these harsh conditions (Collier et al., 1990; Menezes et al., 2007). Rahel (1983) suggested that the tolerance to acidic waters results, in part, from physiological adaptations that allow individuals to survive at low electrolytes concentrations. In addition, reproductive physiology and fish behavior may increase the chances of offspring survivor in blackwater streams. For instance, species which are common to blackwaters in southeastern Brazilian coast as M. lateralis, H. multifasciatus, and Rachoviscus crassiceps are internal inseminating, in which the females keep the sperm until finding suitable environmental conditions to lay and fertilize their eggs (Menezes et al., 2007).

The unexplained variation $(53.8 \%$ with all streams included and $70.6 \%$ only with the clearwater streams) was higher than the variation assigned to the environmental factors, and part of this could be attributed to unmeasured

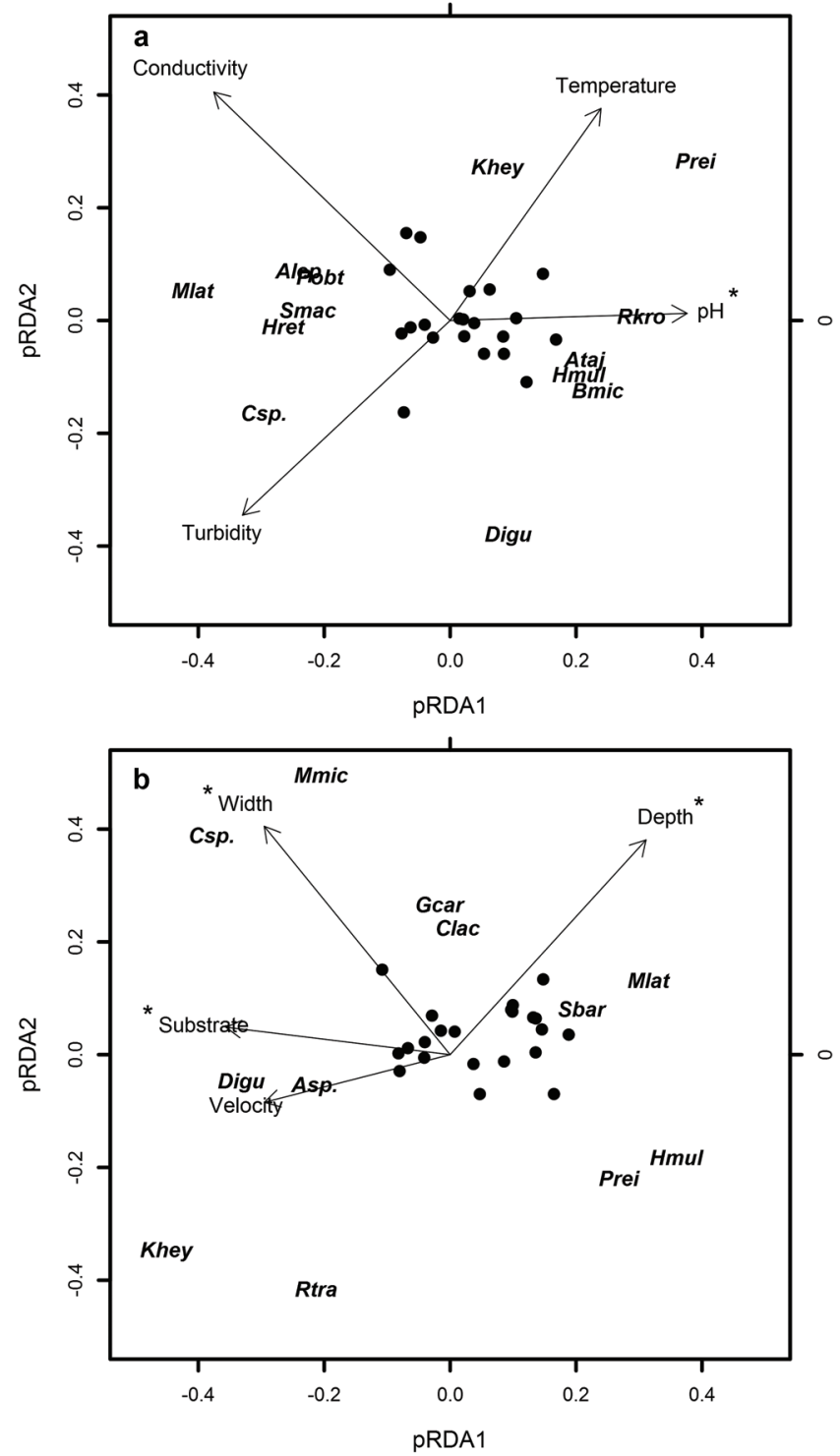

Fig. 3. Results of partial Redundant Analyses (pRDA) showing the patterns of correlation among species abundance with the pure limnological (a), and pure structural (b) predictors. The asterisks indicate environmental variables which were statistically correlated $(\mathrm{p} \leq 0.05)$ with community composition. Only species with eigenvectors higher than 0.2 were identified by their abbreviated symbols. The others were identified by black dots. This limit was arbitrary but chosen to evidence only the species which were mostly correlated with environmental predictors. 
variables (Melo et al., 2011; Landeiro et al., 2012). We did not measure, for example bank slope, riparian vegetation cover, accumulation of wood debris or stream declivity, variables that may influence fish communities (Pulsey \& Arthington, 2003; Cruz et al., 2013; Langford et al., 2012). Nonetheless, given the high magnitude of the unexplained variation, it is improbable that they would significantly improve the percent of explanatory variation.

Part of the unexplained variation could also be due to regional factors influencing the organism's dispersion (Falke $\&$ Fauch, 2010). In stream habitats, the main rivers could function as dispersal corridors, facilitating the movement of individuals among local communities (Brown \& Swan, 2010; Roberts \& Hitt, 2010). We found that 19 out of the 34 species captured in the present study (aproximately 55\%) are present both in streams and the main rivers of the basin (Ferreira \& Petrere Jr., 2009). In addition, Mazzoni et al. (2004) and Mazzoni \& Iglesias-Rios (2007) found evidence of short reproductive migrations for some species of Characidae of Atlantic forest streams, while Mazzoni \& Iglesias-Rios (2012) by means of a mark-recapture experiment, found a group of fishes (Astyanax janeiroensis, A. hastatus, Parotocinclus maculicauda, and Pimelodella lateristriga), which they called "Long Movement group", that moved at least $6 \mathrm{~km}$ within 60 days. Nonetheless, the Mantel test indicated a non-significant influence of site proximities upon assemblage structure, suggesting that including a third spatial matrix would be unhelpfull to reduce significantly the unexplained variation of fish-environment association.

Finally, the unexplained variability could be related to our scale of observation. The 50-m long-stretches that we sampled included a variety of mesohabitats of pools, runs and rapids, mainly in the clearwater streams. The influence of mesohabitats within short stretches of Atlantic forest streams was detected by Rezende et al. (2010). These authors verified that pool, riffle, and run units varying from 2.10 to $11.7 \mathrm{~m}$-long were significant predictors of fish community structure. Other authors also have found that small patches of mesohabitats (5 m-long) have significant influences on functional fish composition in second and third order streams (Teresa \& Casatti, 2012). If mesohabitat heterogeneity within our sampling sites did affect fish composition, which is possible mainly in clearwater streams, averaging the values of habitat predictors and pooling all fishes together might have weakened the observed correlation between fish community composition and local environmental factors and thus, increased the unexplained variation. So far, we cannot test this possibility, but future sampling schemes could be conducted in order to understand how the scale of observation influences our measurement of fish-environment association in these streams.

Despite these possibilities, we verified that high unexplained variances are not unusual in metacommunity studies, and the reasons for these patterns still need of systematic investigations (Melo et al., 2011). For example, Landeiro et al. (2012) partialling out the influences of local environment and space on assemblages of caddisfly larvae in 89 Amazonian streams, found that the percent of unexplained variation ranged from $75.7 \%$ to $85.7 \%$, depending on which assemblage subsets were analyzed. Similar fractions, sometimes much higher than $50 \%$, were also found by Falke \& Fauch (2010), Siqueira et al. (2012), Casatti et al. (2012) and Grönroos et al. (2013), despite the high number of explanatory variables and the high number of sampling sites included in these studies.

The major limitation of the present study was the small sample size. The low number of blackwater sites did not allow us to investigate the patterns of variation within these streams. This low number of blackwaters in comparison to clearwater streams was partially due to the limited accessibility as they are inside the Restinga forest, and partially because this area is predominantly swampy having few small and shallow streams suitable to electrofishing. The same limitation was found by Gonçalves \& Braga (2012) in a nearby basin. On the other hand, the physical habitat structure in clearwater streams (channel width, depth, and substrate) was the main source of variability in community composition.

Despite these limitations, our main conclusions agree with the findings of Gonçalves \& Braga (2012) that the lower levels of $\mathrm{pH}$ are probably the main environmental filter for blackwater fish communities, and that species associated with these habitats may present some degree of specialization (Menezes et al., 2007). Rocha et al. (2007) also stressed that Restinga forests are areas of high endemism threatened by the growing levels of urbanization and fragmentation. Among the five most abundant species, M. lateralis and S. macropterus are classified as endangered due to their association with Restinga forest streams in the southeastern Brazil (Menezes et al., 2007), and recently, another endangered species (Rachoviscus crassiceps) was captured in blackwaters of Itanhaém River basin (Oyakawa \& Menezes, 2011). These results are important from the standpoint of conservation planning for that area, since the degree of urbanization in the Itanhaém city has increased from $85.6 \%$ in 1970 to $99.59 \%$ in 2000 (Pereira, 2002), and because most urbanization pressures are concentrated in the lower stretches of the basin outside from the limits of the Serra do Mar State Park.

\section{Acknowledgments}

This research was founded by Fundação de Amparo à Pesquisa do Estado de São Paulo (FAPESP Process 05/581850) and Conselho Nacional de Desenvolvimento Científico e Tecnológico (CNPq Process 130627/2005-4). Universidade Estadual Paulista "Júlio de Mesquita Filho" (UNESP Instituto de Biociências), Rio Claro campus provided the 
institutional support. Collection licenses were issued by IBAMA (Process n ${ }^{\circ}$. 02027.002343/2005-59) and COTEC (Process $n^{\circ}$. 44.158/2005). We thank Antonio F. M. Camargo for the logistic support during fieldwork, Francisco Langeani (DZSJRP), Heraldo A. Britski (MZUSP), Marcelo R. Britto (MNRJ), Osvaldo T. Oyakawa (MZUSP), and Ilana Fichberg (MZUSP) for helping with species identification and Bruna B. Cruz for comments on early versions of the manuscript.

\section{Literature Cited}

Allan, J. D. \& M. M. Castillo. 2007. Stream Ecology: structure and function of running waters. Dordrecht, Springer.

Angermeier, P. L. \& J. R. Karr. 1984. Relationships between woody debris and fish habitat in a small warmwater stream. Transactions of the American Fisheries Society, 113: 716-726.

Borcard, D., P. Legendre \& P. Drapeau. 1992. Partialling out the spatial component of ecological variation. Ecology, 73: 1045-1055.

Brown, B. L. \& C. M. Swan. 2010. Dendritic network structure constrains metacommunity properties in riverine ecosystems. Journal of Animal Ecology, 79: 571-80.

Buisson, L., L. Blanc \& G. Grenouillet. 2008. Modelling stream fish species distribution in a river network: the relative effects of temperature versus physical factors. Ecology of Freshwater Fish, 17: 244-257.

Camargo, A. F. M., P. R. Nucci, L. M. Bini \& L. Silva Jr. 1996. The influence of the geology on the limnological characteristics of some lotic ecosystems of the Itanhaém River Basin, SP-Brazil. Verhandlungen des Internationalen Verein Limnologie, 26: 860-864.

Casatti, L., C. de P. Ferreira \& F. R. Carvalho. 2009. Grass-dominated stream sites exhibit low fish species diversity and dominance by guppies: an assessment of two tropical pasture river basins. Hydrobiologia, 632: 273-283.

Casatti, L., F. B. Teresa, T. Gonçalves-Souza, E. Bessa, A. R. Manzotti, C. S. Gonçalves \& J. O. Zeni. 2012. From forest to cattail: how does the riparian zone influence stream fish? Neotropical Icthyology, 10: 205-214.

Collier, K. J., O. J. Ball, A. K. Graesser, M. R. Main \& M. J. Winterbourn. 1990. Do organic and anthropogenic acidity have similar effects on aquatic fauna? Oikos, 59: 33-38.

Cruz, B. B., L. E. Miranda \& M. Cetra. 2013. Links between riparian landcover, instream environment and fish assemblages in headwater streams of south-eastern Brazil. Ecology of Freshwater Fish, 22: 607-616.

Dias, M. S., W. E. Magnusson \& J. Zuanon. 2010. Effects of reduced-impact loggin on fish assemblages in Central Amazonia. Conservation Biology, 24: 278-286.

Falke, J. A. \& K. D. Fausch. 2010. From metapopulations to metacommunities: linking theory with empirical observations of the spatial population dynamics of stream fishes. Pp. 207-233. In: Gido, K. B. \& D. A. Jackson (Eds.). Community ecology of stream fishes: concepts, approaches and techniques. Ottawa, American Fisheries Society Special Publication 73.

Ferreira, F. C. \& M. Petrere Jr. 2009. The fish zonation of the Itanhaém River basin in the Atlantic Forest of southeast Brazil. Hydrobiologia, 636: 11-34.

Freda, J. \& W. A. Dunson. 1984. Sodium balance of amphibian larvae exposed to low environmental $\mathrm{pH}$. Physiological Zoology, 57: 435-443.

Fromm, P. O. 1980. A review of some physiological and toxicological responses of freshwater fish to acid stress. Environmental Biology of Fishes, 5: 79-93.

Gerhard, P., R. Moraes \& S. Molander. 2004. Stream fish communities and their associations to habitat variables in a rain forest reserve in southeastern Brazil. Environmental Biology of Fishes, 71: 321-340.

Gonçalves, C. S. \& F. M. S. Braga. 2012. Changes in ichthyofauna composition along a gradient from clearwaters to blackwaters in coastal streams of Atlantic forest (southeastern Brazil) in relation to environmental variables. Neotropical Ichthyology, 10: 675-684.

Grönroos, M., J. Heino, T. Siqueira, V. L. Landeiro, J. Kotanen \& L. M. Bini. 2013. Metacommunity structuring in stream networks: roles of dispersal mode, distance type, and regional environmental context. Ecology and Evolution, 3: 4473-4487.

Hargeby, A. \& R. C. Petersen Jr. 1988. Effects of low pH and humus on the survivorship, growth and feeding of Gammarus pulex (L.) (Amphipoda). Freshwater Biology, 19: 235-248.

Henderson, P. A. \& I. Walker. 1986. On the leaf litter community of the Amazonian blakwater stream Tarumazinho. Journal of Tropical Ecology, 2: 1-16.

Holmes, K. L., P. C. Goebel, L. R. Williams \& M. Schecengost. 2011. Environmental influences on macroinvertebrate assemblages in headwater streams of northeastern Ohio. Journal of Freshwater Ecology, 26: 409-422.

Jackson, D. A., P. R. Peres-Neto \& J. D. Olden. 2001. What controls who is where in freshwater fish communities: the roles of biotic, abiotic, and spatial factors. Canadian Journal of Fisheries and Aquatic Sciences, 58: 157-170.

Janzen, D. H. 1974. Tropical blackwater rivers, animals, and mast fruiting by the Dipterocarpaceae. Biotropica, 6: 69-103.

Landeiro, V. L., L. M. Bini, A. S. Melo, A. M. O. Pes \& W. E. Magnusson. 2012. The roles of dispersal limitation and environmental conditions in controlling caddisfly (Trichoptera) assemblages. Freshwater Biology, 57: 1554-1564.

Langford, T. E. L., J. Langford \& S. J. Hawkins. 2012. Conflicting effects of woody debris on stream fish populations: implications for management. Freshwater Biology, 57: 1096-1111.

Legendre, P. \& L. Legendre. 2012. Numerical ecology. Third English edition. Developments in Environmental Modelling, 24. Oxford, Elsevier.

Legendre, P. 2008. Studying beta diversity: ecological variation partitioning by multiple regression and canonical analysis. Journal of Plant Ecology, 1: 3-8.

Manly, B. F. J. 2007. Randomization, bootstrap and Monte Carlo methods in biology. Third edition. London, Chapman \& Hall/CRC.

Matthews, W. J. 1998. Patterns in Freshwater Fish Ecology. New York, Chapman \& Hall.

Mazzoni, R. \& R. Iglesias-Rios. 2007. Patterns of investment of the reproductive strategy of two stream-dwelling Characidae. Brazilian Journal of Biology, 67: 695-699.

Mazzoni, R. \& R. Iglesias-Rios. 2012. Movement patterns of streamdwelling fishes from Mata Atlântica, Southeast Brazil. Revista de Biología Tropical, 60: 1837-1846.

Mazzoni, R., S. A. Schubart \& R. Iglesias-Rios. 2004. Longitudinal segregation of Astyanax janeiroensis in Rio Ubatiba: a Neotropical stream of south-east. Ecology of Freshwater Fish, 13: 231-234.

Melo, A. S., F. Schneck, L. U. Hepp, N. R. Simões, T. Siqueira \& L. M. Bini. 2011. Focusing on variation: methods and applications of the concept of beta diversity in aquatic ecosystems. Acta Limnologica Brasiliensia, 23: 318-331. 
Menezes, N. A., S. H. Weitzman, O. T. Oyakawa, F. C. T. Lima, R. M. C. Castro \& M. J. Weitzman. 2007. Freshwater fishes of Mata Atlântica: preliminary list of species and comments on conservation of Neotropical freshwater fishes. São Paulo, Museu de Zoologia - Universidade de São Paulo.

Oksanen, J., F. G. Blanchet, R. Kindt, P. Legendre, P. R. Minchin, G. L. Simpson, P. Solymos, M. H. H. Stevens \& H. Wagner. 2012. Vegan: Community Ecology Package. R package version 2.0-4. Available from: http://cran.r-project.org/web/packages/vegan.

Otto, G. 2006. Ecologia trófica de duas espécies de Mimagoniates (Characiformes: Characidae: Glandulocaudinae) em riachos na Ilha de São Francisco - SC. Unpublished M.Sc. Dissertation, Universidade Federal do Paraná, 86p.

Oyakawa, O. T. \& N. A. Menezes. 2011. Checklist dos peixes de água doce do Estado de São Paulo, Brasil. Biota Neotropica, 11: 1-13.

Peel, M. C., B. L. Finlayson \& T. A. McMahon. 2007. Updated world map of the Köppen-Geiger climate classification. Hydrology and Earth System Sciences, 11: 1633-1644.

Peltonen, H., M. Luoto, J. P. Pääkkönen, M. Karjalainen, A. Tuomaala, J. Pönni \& M. Viitasalo. 2007. Pelagic fish abundance in relation to regional environmental variation in the Gulf of Finland, northern Baltic Sea. ICES Journal of Marine Science, 64: 487-495.

Pereira, L. A. 2002. Análise ambiental da bacia do rio Itanhaém baseada na relação entre aspectos limnológicos com fisiografia, uso da terra e sistema hidrológico, SP. Unpublished M.Sc. Dissertation. Universidade Estadual Paulista "Júlio de Mesquita Filho", 78p.

Peres-Neto, P. R., P. Legendre, S. Dray \& D. Borcard. 2006. Variation partitioning of species data matrices: estimation and comparison of fractions. Ecology, 87: 2614-2625.

Por, F. D. 2004. Hidrobiologia da Juréia e da baixada do Ribeira: rios e manguezais. Pp. 51-57. In: Marques, O. A. V., W. Duleba (Eds.). Estação Ecológica Juréia-Itatins: ambiente físico, flora e fauna. Ribeirão Preto, Holos.

Pulsey, B. J. \& A. H. Arthington. 2003. Importance of riparian zone to the conservation and management of freshwater fish: a review. Marine and Freshwater Research, 54: 1-16.

R Development Core Team, 2012. R: A language and environment for statistical computing. Vienna, Austria, R Foundation for Statistical Computing. http://www.R-project.org.

Rahel, F. J. 1983. Population differences in acid tolerance between yellow perch, Perca flavescens, from naturally acidic and alkaline lakes. Canadian Journal of Zoology, 61: 147-152.
Rezende, C. F., M. Moraes, L. R. Manna, R. P. Leitão, E. P. Caramashi \& R. Mazzoni. 2010. Mesohabitat indicator species in a coastal stream of the Atlantic rainforest, Rio de Janeiro-Brazil. Revista de Biologia Tropical, 58: 1479-1487.

Roberts, J. H. \& N. H. Hitt. 2010. Longitudinal structure in temperate stream fish communities: evaluating conceptual models with temporal data. Pp. 281-299. In: Gido, K. B. \& D. A. Jackson (Eds.). Community ecology of stream fishes: concepts, approaches and techniques. Ottawa, American Fisheries Society Special Publication 73.

Rocha, C. D. F., H. G. Bergallo, M. Van Sluys, M. A. S. Alves \& C. E. Jamel. 2007. The remnants of restinga habitats in the brazilian Atlantic Forest of Rio de Janeiro State, Brazil: habitat loss and risk of disappearance. Brazilian Journal of Biology, 67: 263-273.

São Paulo, 2012. SIGRH - Sistema de Informações para o Gerenciamento de Recursos Hídricos do Estado de São Paulo. Secretaria de Saneamento e Recursos Hídricos. Available from: http://www.sigrh.sp.gov.br. (05 Dec 2012).

Schlosser, I. J. 1982. Fish community structure and function along two habitat gradients in a headwater stream. Ecological Monographs, 52: 395-414.

Simpson, G. L. 2012. Permute: Functions for generating restricted permutations of data. $\mathrm{R}$ package version $0.7-0$.

Siqueira, T., L. M. Bini, F. O. Roque, S. R. M. Couceiro, S. Trivinho-Strixino \& K. Cottenie. 2012. Common and rare species respond to similar niche processes in macroinvertebrate metacommunities. Ecography, 34: 1-10.

Súarez, Y. R. \& M. Petrere Jr. 2007. Environmental factors predicting fish community structure in two neotropical rivers in Brazil. Neotropical Ichthyology, 5: 61-68.

Taylor, C. M., M. R. Winston \& W. J. Matthews. 1993. Fish speciesenvironment and abundance relationships in a Great Plains river system. Ecography, 16: 16-23.

Teresa, F. B. \& L. Casatti. 2012. Influence of forest cover and mesohabitat types on functional and taxonomic diversity of fish communities in Neotropical lowland streams. Ecology of Freshwater Fish, 21: 433-442.

Submitted June 14, 2013

Accepted December 21, 2013 by Fabrício Teresa

Published March 31, 2014 